\title{
KARAKTERISASI FRAKSI AMONIUM SULFAT TRIPSIN YANG DIISOLASI DARI USUS IKAN TONGKOL (Euthynnus affinis)
}

\author{
Tati Nurhayati*, Roni Nugraha, Diana Ningdya Lihuana \\ Departemen Teknologi Hasil Perairan, Fakultas Perikanan dan Ilmu Kelautan, Institut Pertanian Bogor \\ *Korespondensi: nurhayati7870@yahoo.com \\ Diterima: 20 Juli 2020/ Disetujui: 31 Agustus 2020
}

Cara sitasi: Nurhayati T, Nugraha R, Lihuana DN. 2020. Karakterisasi fraksi amonium sulfat tripsin yang diisolasi dari usus ikan tongkol (Euthynnus affinis). Jurnal Pengolahan Hasil Perikanan Indonesia. 23(2): $372-382$

\begin{abstract}
ABSTRAK
Usus ikan tongkol merupakan bagian saluran pencernaan ikan yang memiliki $\mathrm{pH}$ neteral sehingga berpotensi sebagai sumber enzim, yaitu enzim tripsin. Enzim tripsin dari jeroan ikan bisa menjadi alternatif dari enzim tripsin komersil yang berasal dari babi dan sapi. Penelitian ini bertujuan menganalisis karakteristik fraksi amonium sulfat enzim tripsin dari usus ikan tongkol. Tahapan penelitian diawali dengan ekstraksi enzim tripsin dari usus ikan tongkol lalu difraksinasi menggunakan amonium sulfat (0-80\%). Fraksi terbaik dikarakterisasi suhu, $\mathrm{pH}$, pengaruh ion logam, stabilitas terhadap $\mathrm{NaCl}$, dan substrat optimum serta dilakukan analisis kinetika reaksi. Pengukuran aktivitas enzim menggunakan substrat $N$ - $\alpha$-benzoylDL-arginine-p-nitroanilide (BAPNA). Hasil penelitian menunjukkan bahwa ekstrak kasar tripsin memiliki aktivitas sebesar 0,205 $\mathrm{U} / \mathrm{mL}$. Aktivitas enzim tripsin tertinggi terdapat pada fraksi amonium sulfat fraksi $40-50 \%$ sebesar $0,248 \mathrm{U} / \mathrm{mL}$. Enzim bekerja optimum bekerja pada suhu $60^{\circ} \mathrm{C}$ dan $\mathrm{pH}$ 9. Ion logam $\mathrm{ZnCl}_{2}$ dan $\mathrm{CaCl}_{2}$ menghambat aktivitas tripsin, sedangkan $\mathrm{MnCl}_{2}, \mathrm{CuCl}_{2}$, dan $\mathrm{NaCl}$ dapat meningkatkan aktivitas tripsin. Aktivitas tripsin stabil pada $\mathrm{NaCl} 5-30 \%$. Enzim tersebut memiliki nilai $\mathrm{V}_{\text {maks }}$ sebesar $0,42 \mathrm{mmol} / \mathrm{s}$ dan nilai Nilai $\mathrm{K}_{\mathrm{m}}$ sebesar $1,12 \mathrm{mM}$
\end{abstract}

Kata kunci: BAPNA, enzim tripsin, fraksi amonium sulfat, ikan tongkol, jeroan ikan

\section{Characterization of Ammonium Sulphate Fraction Tripsin Isolated from Intestine of Little Tuna \\ ABSTRACT}

Intestine is part of the digestive tract of fish having neutral $\mathrm{pH}$. Thus, fish intestine is a potential source of typsin and can be an alternative source to the commercial trypsin enzyme derived from pork and cattle. This study was aimed to analyze the characteristics of the ammonium sulphates fraction of the trypsin enzyme from tuna intestine. The research began with the extraction of the trypsin enzyme from the little tuna intestine and followed up by fractionation using ammonium sulphates (0-80\%). Optimum temperature and $\mathrm{pH}$ as well as effects of metal ions, stability to $\mathrm{NaCl}$, optimum substrate and reaction kinetics were determined. Enzyme activity was measured using N- $\alpha$-benzoyl-DL-arginine-p-nitroanilide (BAPNA). The results showed that the trypsin crude extract had an activity of $0.205 \mathrm{U} / \mathrm{mL}$. The highest enzyme activity was found in the ammonium sulphates fraction of $40-50 \%$. The enzyme worked optimally at $60^{\circ} \mathrm{C}$ and $\mathrm{pH}$ 9. Metal ions including $\mathrm{ZnCl}_{2}$ and $\mathrm{CaCl}_{2}$ inhibited trypsin activity, while $\mathrm{MnCl}_{2}, \mathrm{CuCl}_{2}$, and $\mathrm{NaCl}$ increased trypsin activity. Trypsin activity was stable at $5-30 \% \mathrm{NaCl}$. The enzyme had a $\mathrm{V}_{\max }$ value of $0.42 \mathrm{mmol} / \mathrm{s}$ and a $\mathrm{K}_{\mathrm{m}}$ value of $1.12 \mathrm{mM}$.

Keywords: ammonium sulfate fraction, BAPNA, viscera, little tuna, trypsin enzyme 


\section{PENDAHULUAN}

Enzim yang dibutuhkan untuk industri di Indonesia, sebesar 99\% masih diimpor dari negara lain. Penggunaan enzim di Indonesia mencapai 2.500 ton dengan nilai impor 200 milyar pada tahun 2017. Kebutuhan enzim di Indonesia cenderung meningkat setiap tahun dan diperkirakan permintaan pasar terhadap enzim akan meningkat sekitar 5-7\% per tahun dalam kurun waktu 2015 sampai 2020 (Kemeristekdikti 2017). Enzim banyak digunakan dalamberbagaiproses kimiawipada bidang industri dan bioteknologi. Gimenes et al. (2019) menjelaskan bahwa enzim protease banyak diaplikasikan pada berbagai industri. Protease alkali diaplikasikan di industri kulit, kertas, pulp, deterjen, tekstil, industri makanan dan farmasi. Enzim protease lain yang banyak digunakan di industri adalah pepsin. Enzim tersebut memiliki kemampuan untuk membekukan kasein selama pembuatan keju.

Tripsin merupakan salah satu enzim yang termasuk golongan enzim proteolitik atau protease serin yang diproduksi di pankreas. Tripsin bekerja mengkatalisis reaksi pemecahan protein dengan menghidrolisis ikatan peptida antara asam amino lisin dan arginin menjadi senyawa yang lebih sederhana (Sulistyowati et al. 2016). Enzim tripsin berada dalam bentuk inaktif yaitu tripsinogen ketika diproduksi di pankreas. Aktivasi tripsinogen menjadi tripsin akan mengaktivasi enzim lainnya pada sistem pencernaan sehingga keberadaan tripsin sangat penting untuk memulai pencernaan di usus (Teich et al. 2005). Tripsin merupakan enzim yang umumnya digunakan untuk melepaskan sel vero dari mikrokarrier pada proses produksi vaksin. Tripsin komerisal saat ini umumnya diperoleh dari ekstraksi protease menggunakan asam atau alkohol dari pankreas mamalia, umumnya babi (Parfitt 1999).

Penggunaan pankreas babi sebagai bahan baku dalam pembuatan enzimmerupakan hal yang kontroversial di masyarakat Indonesia yang mayoritasnya muslim karena masalah kehalalannya (Muallifah 2017). Sapi dapat dijadikan sebagai alternatif sumber tripsin. Namun, tripsin dari sapi belum umum penggunaannya serta dikhawatirkan terjangkit penyakit bovine spongiform encephalopathy (BSE) yang popular sebagai penyakit sapi gila sehingga penggunaan tripsin dari sapi masih dihindari (Ranasasmita dan Roswiem 2015). Hal ini mendorong perlunya subtitusi dengan bahan utama lain misalnya ikan.

Industri perikanan di Indonesia menghasilkan limbah dalam volume yang cukup besar. Moniharapon dan Pattipeilohy (2016) menyatakan bahwa rendemen limbah ikan tuna mencapai $60,3 \%$ yang terdiri atas $23,1 \%$ daging merah, $17,8 \%$ kepala, $8,5 \%$ tulang dan sirip, 3,7\% kulit, 3,2\% isi perut, $0,9 \%$ darah, dan $0,6 \%$ jantung. Akan tetapi, jumlah limbah yang besar ini belum dimanfaatkan dan berpotensi mencemari lingkungan. Tingginya produksi perikanan diikuti dengan tingginya limbah yang dihasilkan perlu diimbangi dengan penanganan dan pemanfaatan limbah. Li et al. (2006) menyatakan bahwa jeroan ikan tuna bagian spleen merupakan sumber enzim protease. Pasaribu et al. (2018) berhasil mengisolasi pepsin dari lambung tuna. Khandagale et al. (2017) dengan sampel Sardinella longiceps dan Barkia et al. (2010) dengan sampel Boops boops menemukan adanya aktivitas enzim tripsin pada jeroan ikan. Kim dan Jeong (2012) melaporkan bahwa jeroan bagian usus ikan Paralichthys olivaceus juga menemukan aktivitas enzim tripsin. Pemanfaatan jeroan ikanyang belum optimal mendorong pada penelitian ini untuk menganalisis karakteristik fraksi amonium sulfat tripsin yang diekstrak dari usus ikan tongkol.

\section{BAHAN DAN METODE Bahan dan Alat}

Bahan yang digunakan dalam penelitian iniyaitu jeroan ikan tongkol, dimetil sulfoksida (Merck, for analysis), amonium sulfat, tris base (sigma), hydrocloric acid (Merck, for analysis), asam asetat (Merck KGaA), $N-\alpha-$ benzoyl-DL-arginine-p-nitroanilida (BAPNA) (Sigma), bovine serum albumin (BSA), akuades, $\mathrm{CaCl}_{2} 2 \mathrm{H}_{2} \mathrm{O}$ (Merck), $\mathrm{MnCl}_{2}$ (Merck), $\mathrm{CuCl}_{2}$ (Merck) $\mathrm{ZnCl}_{2}$ (Merck) $\mathrm{CaCl}_{2}$ (Merck) dan $\mathrm{NaCl}$ (Merck).

Alat yang digunakan meliputi waterbath, centrifuge (BECKMEN model J2-21), mini 
centrifuge (centurion scientific K240), spektrofotometer UV-Vis (Labomed).

\section{Metode Penelitian}

Penelitian ini dilakukan melalui tiga tahapan. Tahapan pertama yaitu preparasi sampel dan pengukuran morfometrik, selanjutnya ekstraksi enzim, pengendapan ekstrak kasar enzim dengan amonium sulfat dan karakterisasi enzim tripsinfraksi terbaik.

\section{Preparasi sampel dan pengukuran morfometrik}

Usus ikan tongkol yang telah bersih disimpan dalam freezer $\left(-20^{\circ} \mathrm{C}\right)$ guna meminimalisirautolisis protease. Morfometrik yang diukur meliputi panjang usus, lebar usus, dan bobot usus. Usus dipotong menjadi ukuran yang lebih kecil $(2-4 \mathrm{~cm})$.

\section{Ekstraksi enzim tripsin (Barkia et al. 2010)}

Usus ikan dihaluskan hingga lumat kemudian dihomogenisasi menggunakan buffer tris-HCl0.01 M pH 8 dengan rasio 1:4 $(\mathrm{b} / \mathrm{v})$. Kemudian disentrifugasi selama 30 menit pada suhu $4^{\circ} \mathrm{C}$ dengan kecepatan 9.500 g. Supernatan yang diperoleh merupakan ekstrak kasar enzim. Ekstrak kasar enzim tripsin (supernatan) diukur kadar protein (Bradford 1976) dan aktivitas enzim (Silva et al. 2011).

\section{Pengendapan ekstrak kasar enzim tripsin dengan amonium sulfat (Barkia et al. 2010)}

Supernatan yang diperoleh dari tahap ekstraksi diendapkan dengan amonium sulfat yang berfraksi. Fraksi amonium sulfat yang digunakan adalah $0-10 \%, 10-20 \%, 20-30 \%$, $30-40 \%, 40-50 \%, 50-60 \%, 60-70 \%, 70-80 \%$ (b/ v). Sampel ditempatkan ke dalam tabung reaksi dan suhu labu dikondisikan menjadi $4^{\circ} \mathrm{C}$ menggunakan es gel. Penambahan larutan amonium sulfat dilakukan dengan dituang sedikit demi sedikit ke dalam larutan enzim sambil diaduk. Proses pengadukan membutuhkan waktu \pm 45 menit. Larutan enzim lalu disentrifugasi dengan kecepatan 11,800 g selama 30 menit pada suhu $4^{\circ} \mathrm{C}$. Endapan kemudian dipisahkan dari cairannya.
Cairan yang tersisa dicatat volumenya untuk digunakan pada pengendapan fraksi selanjutnya. Endapan yang dihasilkan pada tahap ini dianalisis kadar protein (Bradford 1976) dan aktivitas enzim (Silva et al. 2011).

\section{Karakterisasi enzim tripsin fraksi terbaik amonium sulfat}

Karakterisasi enzim tripsin yang dilakukan meliputi penentuan suhu dan $\mathrm{pH}$ optimum, pengaruh ion logam, dan pengaruh konsentrasi $\mathrm{NaCl}$ terhadap aktivitas enzim tersebut, danpenentuan kinetika reaksi. Suhu optimum enzim tripsin ditentukan dengan melakukan variasi suhu inkubasi (20$70^{\circ} \mathrm{C}$ ). Penentuan $\mathrm{pH}$ optimum dilakukan dengan menambahkan buffer TrisCl 0,05M $\mathrm{pH}$ 5-10. Beberapa logam yang digunakan untuk menentukan pengaruhnya terhadap aktivitas enzim tripsin, yaitu $\mathrm{NaCl}, \mathrm{MnCl}_{2}$, $\mathrm{ZnCl}_{2}, \mathrm{CuCl}_{2}$, dan $\mathrm{CaCl}_{2}$. Konsentrasi $\mathrm{NaCl}$ yang digunakan untuk mengetahui stabilitas enzim tripsin adalah $5 \%, 10 \%, 15 \%, 20 \%, 25 \%$, dan 30\%.(b/v) Konsentrasi substrat yang digunakan untuk menentukan kinetika reaksi adalah $1-3,5 \%(\mathrm{~b} / \mathrm{v})$.

\section{Analisis kadar protein (Bradford 1976)}

Sebanyak $0,1 \mathrm{~mL}$ larutan enzim ditambahkan ke dalam tabung berisi $5 \mathrm{~mL}$ pereaksi Bradford. Perlakuan pada blanko, larutan enzim diganti dengan akuades. Larutan tersebut divorteks dan diinkubasi selama 5 menit pada suhu $35^{\circ} \mathrm{C}$. Absorbansi larutan diukur pada panjang gelombang $595 \mathrm{~nm}$. Standar protein yang digunakan adalah BSA dengan konsentrasi $0-1 \mathrm{mg} / \mathrm{mL}$. Konsentrasi protein larutan enzim ditentukan berdasarkan persamaan garis linear hubungan antara konsentrasi standar protein dengan absorbansi.

\section{Analisis aktivitas enzim (Silva et al. 2011 yang dimodifikasi)}

Aktivitas enzim tripsin ditentukan menggunakan substrat spesifik tripsin yaitu BAPNA. Larutan BAPNA dibuat dengan melarutkan 0,0435 g BAPNA dalam $1 \mathrm{~mL}$ DMSO, kemudian dilarutkan dengan Tris $\mathrm{HCl}$ $0,05 \mathrm{M}$ yang mengandung $\mathrm{CaCl}_{2} 2 \mathrm{H}_{2} \mathrm{O} 0,02 \mathrm{M}$ 
sampai $100 \mathrm{~mL}$. Selanjutnya sampel sebanyak $0,05 \mathrm{~mL}$ ditambahkan larutan BAPNA sebanyak 2,5 $\mathrm{mL}$, kemudian diinkubasi pada suhu $37^{\circ} \mathrm{C}$ selama 10 menit. Larutan asetat $30 \%$ ditambahkan sebanyak $1 \mathrm{~mL}$, lalu diinkubasi lagi pada suhu $37^{\circ} \mathrm{C}$ selama 10 menit. Absorbansi sampel diukur pada spektrofotometer dengan panjang gelombang $410 \mathrm{~nm}$. Aktivitas enzim dihitung berdasarkan persamaan :

Aktivitas enzim $(U)=\frac{(\text { Asampel- } \text { Ablanko }) \times \text { volume total setelah direaksikan } \times 1000}{8800 \times \text { waktu inkubasi } \times \text { volume enzim yang direaksikan }}$

\section{Analisis Data}

Data kuantitatif hasil penelitian diolah menggunakan aplikasi Microsoft Excel 2010 dengan menghitung nilai tengah dan standar deviasinya. Data disajikan dalam bentuk tabel dan dijelaskan secara deskriptif. Penelitian dilakukan dengan dua kali pengulangan pada setiap parameter uji.

\section{HASIL DAN PEMBAHASAN Morfometrik Usus Ikan Tongkol}

Ikan tongkol memiliki panjang berkisar 11,7-55,4 cm (Chodrija et al. 2013). Usus ikan tongkol yang digunakan dalam penelitian memiliki berat $4,43 \pm 086 \mathrm{~g}$ dan panjang $25,27 \pm 1,17 \mathrm{~cm}$. Hasil penelitian juga menunjukkan bahwa rendemen jeroan ikan tongkol sebesar $12,30 \pm 0,43 \%$ dan rendemen usus sebesar $6,75 \pm 1,13 \%$ dari total jeroan ikan. Berdasarkan cara makannya, ikan tongkol termasuk golongan karnivora sehingga memiliki panjang usus 0,5-2,4 kali panjang tubuhnya (Kramer dan Bryant 1995). German et al. (2004) melaporkan bahwa ikan yang termasuk karnivora, contohnya Anoplarchus purpurescens, memiliki peningkatan aktivitas tripsin yang lebih cepat dibandingkan dengan jenis ikan lainnya.

\section{Aktivitas Ekstrak Kasar Tripsin dari Usus Tongkol}

Ekstrak kasar tripsin merupakan supernatan dari hasil sentrifugasi pertama setelah usus tongkol dilumatkan dan dihomogenisasikan dengan buffer tris- $\mathrm{HCl}$. Tripsin yang diperoleh diuji aktivitasnya menggunakan substrat BAPNA. Nilai aktivitas ekstrak kasar tripsin dapat dilihat pada Table 1.

Aktivitas ekstrak kasar tripsin yang diperoleh yaitu $0,205 \mathrm{U} / \mathrm{mL}$ dengan total aktivitas 11,48 U. Konsentrasi protein enzim tripsin sebesar $0,7 \mathrm{mg} / \mathrm{mL}$ dengan total protein sebesar 39,2 mg. Dengan demikian aktivitas spesifik ekstrak kasar enzim tripsin sebesar 0,29 U/mg. Kim dan Jeong(2012) melaporkan bahwa enzim tripsin-like yang diperoleh dari usus ikan pipih (paralichthys olivaceus) memiliki aktivitas sebesar $94 \mathrm{U} /$ mg. Kim dan Jeong (2013) menyatakan bahwa satuan unit (U) menunjukkan kuantitas enzim yang mengkatalisis reaksi $1 \mu \mathrm{mol}$ substrat permenit pada kondisi optimum. Usus ikan tongkol diekstrak menggunakan buffer tris- $\mathrm{HCl}$ dengan $\mathrm{pH}$ 8. Penggunaan pelarut buffer Tris- $\mathrm{HCl}$ dapat menjaga kestabilan $\mathrm{pH}$ selama proses ekstraksi. Penggunaan $\mathrm{pH}$ 8 karena enzim tripsin menurut penjelasan Benjakul et al. (1997) merupakan enzim yang termasuk protease alkali. Metode penelitian menggunakan substrat BAPNA dalam buffer tris- $\mathrm{HCl}$, dilanjutkan dengan menghentikan aktivitas enzim menggunakan asam asetat yang bersifat asam.

\section{Fraksi Tripsin dari Usus Ikan Tongkol setelah Pengendapan dengan Amonium Sulfat}

Ekstrak kasar enzim tripsin diendapkan menggunakan amonium sulfat. Proses pengendapan amonium sulfat dilakukan dengan fraksi $0-10 \%, 10-20 \%, 20-30 \%, 30-$

Table 1 Comparasion of tripsin activity between crude extract versus fraction of ammonium sulphates $40-50 \%$

\begin{tabular}{lcrrrrrrr}
\hline \multicolumn{1}{c}{ Step } & $\begin{array}{c}\text { Volume } \\
(\mathrm{mL})\end{array}$ & $\begin{array}{c}\text { Protein } \\
(\mathrm{mg} / \mathrm{mL})\end{array}$ & $\begin{array}{c}\text { Enzyme } \\
\text { activity } \\
(\mathrm{U} / \mathrm{mL})\end{array}$ & $\begin{array}{c}\text { Total of } \\
\text { activity } \\
(\mathrm{U})\end{array}$ & $\begin{array}{c}\text { Total of } \\
\text { protein } \\
(\mathrm{mg})\end{array}$ & $\begin{array}{r}\text { Specificity } \\
\text { of activity } \\
(\mathrm{U} / \mathrm{mg})\end{array}$ & $\begin{array}{c}\text { Yield } \\
(\%)\end{array}$ & Fold \\
\hline Crude extract & 56 & 0.700 & 0.205 & 11.48 & 39.20 & 0.29 & 100.00 & 1 \\
$40-50 \%$ fraction & 18 & 0.646 & 0.248 & 4.46 & 11.63 & 0.38 & 29.66 & 1.31 \\
\hline
\end{tabular}


$40 \%, 40-50 \%, 50-60 \%, 60-70 \%$, dan $70-80 \%$ selama 45 menit kemudian disentrifugasi. Pellet yang dihasilkan diuji aktivitas enzim. Hasil pengujian aktivitas enzim dapat dilihat pada Figure 1.

Figure 1. menunjukkan nilai aktivitas tripsin yang berbeda-beda setelah pengendapan dengan amonium sulfat pada setiap fraksi. .Aktivitas enzim tripsin tertinggi terdapat pada fraksi $40-50 \%$ sebesar 0,248 U/ $\mathrm{mL}$. Aktivitas ini meningkat dibandingkan dengan aktivitas ekstrak kasar enzim. Proses pengendapan memurnikan enzim sebesar 1,32 kali. Perbandingan aktivitas enzim ekstrak kasar dengan aktivitas fraksi terbaik dapat dilihat pada Table 1. Ekstraksi tripsin oleh Santos et al. (2016) menggunakan spesies ikan Luphiosilurus alexandri menunjukkan bahwa fraksi yang terbaik yaitu pada 40-60\%. Hasil tersebut sejalan dengan penelitian yang dilakukan karena masih berada dalam kisaran 40-60\%. Khandagale et al. (2017) dengan sampel Sardinella longiceps mendapatkan hasil pemurnian 1,7 kali dengan pengendapan 30$70 \%$ amonium sulfat. Hasil penelitian yang diperoleh Barkia et al. (2010) menunjukkan aktivitas tripsin fraksi amonium sulfat yang diisolasi dari jeroan ikan Bogou (Boops boops) memiliki aktivitas sebesar $0,6 \mathrm{U} / \mathrm{mL}$.

Pengendapan dengan amonium sulfat bertujuan untuk meningkatkan aktivitas dengan cara mengurangi kandungan senyawasenyawa lain dari ekstrak kasar enzim. Kelebihan metode ini yaitu sederhana, murah, dan tidak akan merusak enzim. Pengendapan dengan amonium sulfat akan mempengaruhi kelarutan protein. Burgess (2009) menjelaskan bahwa garam yang banyak digunakan dalam mengendapkan protein salah satunya adalah amonium sulfat $\left(\mathrm{NH}_{4}\right)_{2} \mathrm{SO}_{4}$ Amonium sulfat sering digunakan pada proses karena tingkat kelarutannya yang tinggi sehingga membuat larutan memiliki kekuatan ionik yang tinggi, hal itu diperkuat dengan pernyataan bahwa $\mathrm{NH}_{4}^{+}$dan $\mathrm{SO}_{4}^{2-}$ menunjukkan stabilitas yang tinggi terhadap pengikatan struktur protein. Salting out terjadi akibat kompetisi antara ion-ion dari garam amonium dan molekul enzim dalam berinteraksi dengan molekul air. Tingginya kadar ion menyebabkan molekul protein berinteraksi dengan molekul protein lainnya sehingga membentuk endapan (Kita et al. 1994). Pengendapan ini tidak akan menyebabkan struktur protein dari enzim rusak dan kehilangan aktivitasnya apabila dilakukan pada suhu $5-10^{\circ} \mathrm{C}$ (Sinaga et al. 2014).

\section{Suhu Optimum Tripsin Usus Ikan Tongkol Fraksi Terbaik}

Pengaruh suhu terhadap aktivitas tripsin diuji dengan menginkubasi enzim pada suhu 20, 30, 40, 50, 60 dan $70^{\circ} \mathrm{C}$. Aktivitas enzim meningkat seiring dengan meningkatnya suhu yang digunakan dan mencapai maksimum pada suhu $60^{\circ} \mathrm{C}$ sebesar $0,461 \mathrm{U} /$ mL. Suhartono (1989) melaporkan bahwa suhu yang meningkat sampai suhu optimum menyebabkan kecepatan reaksi enzim naik karena energinya bertambah. Energi yang meningkat akan mempercepat gerak vibrasi, translasi, dan rotasi enzim dan substrat sehingga memperbesar peluang enzim dan substrat bereaksi. Selain itu, suhu yang

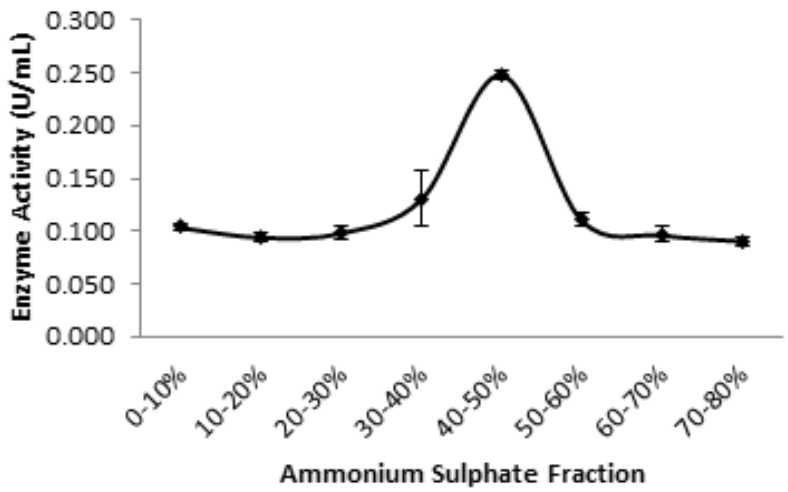

Figure 1 Activity of trypsin after precipitation with ammonium sulfate (0-80\%) 


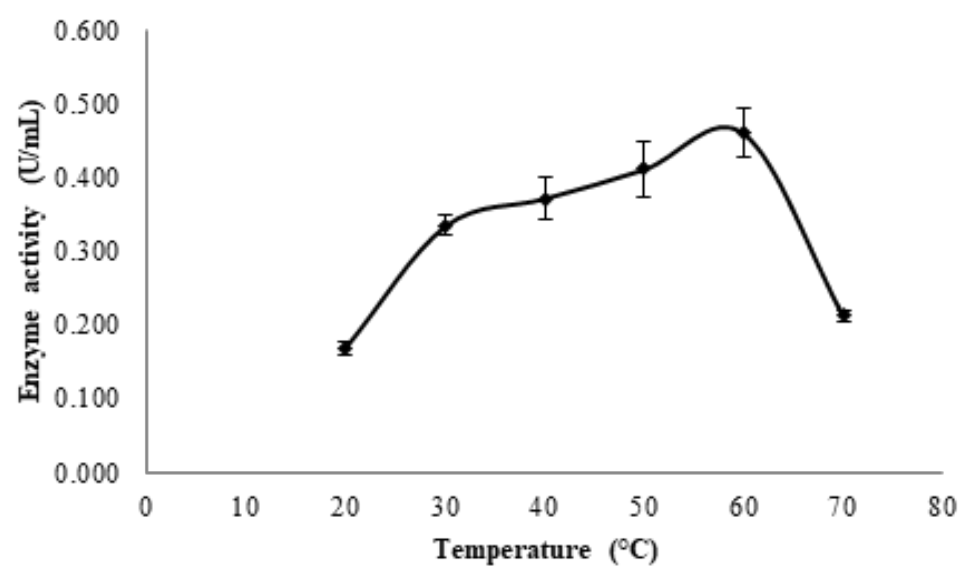

Figure 2 Trypsin activity of little tuna at $\mathrm{pH} 8$ with different temperature

meningkat dapat meningkatkan frekuensi tumbukan antara molekul enzim dan substrat sehingga mengaktifkan enzim (Yazid 2006). Namun, Suhartono (1989) menyatakan bahwa meningkatnya suhu melebihi suhu optimum dapat menyebabkan enzim terdenaturasi dan menghentikan aktivitas katalisinya, serta substrat akan mengalami perubahan konformasi, sehingga substrat tidak dapat berikatan dengan sisi aktif enzim. Hal tersebut mengakibatkan tidak terbentuknya kompleks enzim dengan substrat sehingga aktivitas enzim menurun. Aktivitas tripsin dengan suhu inkubasi yang berbeda dapat dilihat pada Figure 2.

Khandagale etal. (2017)yang menggunakan sampel Sardinella longiceps melaporkan hasil suhu optimum sejalan dengan enzim tripsin ikan tongkol. Namun suhu optimum enzim tripsin ikan tongkol lebih tinggi dibandingkan hasil penelitiaan Bougatef et al. (2007) yang menggunakan sampel Sardina pilchardus dengan aktivitas maksimum pada suhu $55^{\circ} \mathrm{C}$, dan lebih rendah dari penelitian Balti et al. (2009) dimana aktivitas maksimumnya pada suhu $70^{\circ} \mathrm{C}$. Lingkungan hidup ikan dapat mempengaruhi suhu optimum tripsin (Kim dan Jeong 2012). Oktavianto et al. (2009) menyatakan bahwa suhu air dapat mempengaruhi proses enzimatis dalam tubuh ikan. Grizelle dan Rogers (2003) juga menyatakan bahwa suhu lingkungan hewan akuatik mempengaruhi proses fisiologis dalam tubuh, salah satunya aktivitas enzim.

Aktivitas enzim tripsin ikan tongkol pada suhu $70^{\circ} \mathrm{C}$ mengalami penurunan yang cukup drastis, hal ini disebabkan oleh sebagian protein telah terdenaturasi. Suhu yang tinggi akan menyebabkan putusnya ikatan hidrogen, ikatan ion, atau interaksi hidrofobik sehingga struktur enzim berubah mengakibatkan terjadinya penurunan aktivitas enzim (Whitaker 1994). Suhu optimum pada enzim mengefektifkan ikatan antara enzim dan substrat sehingga pembentukan kompleks enzim dan substrat semakin mudah dan aktivitasnya akan meningkat. Kenaikan pada suhu optimum menyebabkan aktivitas enzim meningkat karena suhu tinggi dapat meningkatkan energi kinetik yang mempercepat vibrasi, translasi, dan rotasi substrat dan enzim yang memudahkan terbentuknya kompleks enzim dan substrat (Kosim 2009).

\section{pH Optimum Tripsin Usus Ikan Tongkol Fraksi Terbaik}

Enzim tripsin dari usus ikan tongkol diuji karakteristik $\mathrm{pH}$ optimum. Analisis pengaruh derajat keasaman pada aktivitas tripsin dilakukan menggunakan substrat dengan pH yang berbeda yaitu 5, 6, 7, 8, 9, dan 10 . Hasil pengujian pengaruh nilai $\mathrm{pH}$ terhadap aktivitas enzim dapat dilihat pada Figure 3.

Figure 3 menunjukkan hasil analisis aktivitas enzim dengan $\mathrm{pH}$ yang berbeda. Aktivitas enzim meningkat seiring dengan meningkatnya $\mathrm{pH}$ yang digunakan, namun sedikit mengalami penurunan pada $\mathrm{pH} 10$. Aktivitas enzim tertinggi pada $\mathrm{pH} 9$ sebesar $0,67 \mathrm{U} / \mathrm{mL}$. Hasil ini sesuai dengan penelitian sebelumnya oleh Santos et al. (2016) dan 


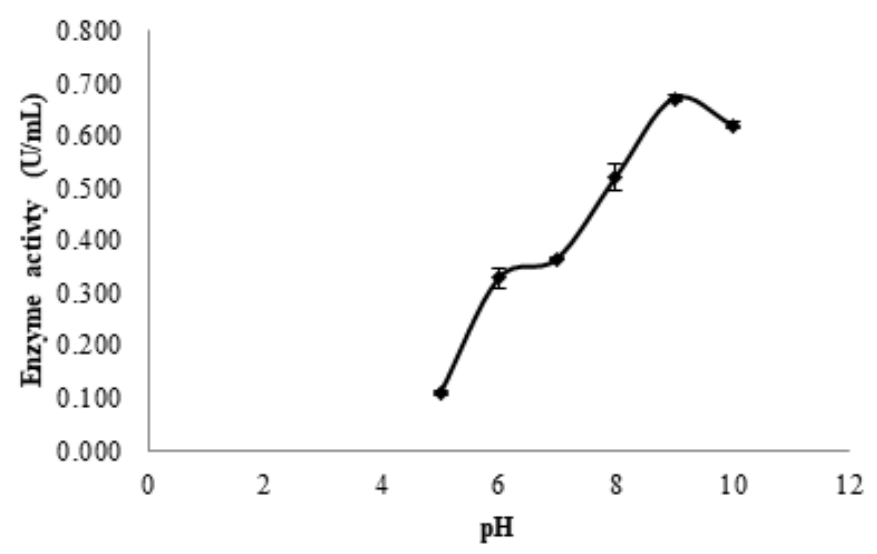

Figure 3 Trypsin activity of little tuna at temperature $60^{\circ} \mathrm{C}$ at different $\mathrm{pH}$

Barkia et al. (2010) dimana pH optimumnya adalah 9.

Kenaikan pH (basa) atau penurunan $\mathrm{pH}$ (asam) dapat menyebabkan penurunan aktivitas enzim dengan cepat hingga menghentikan aktivitas katalitiknya. Hal ini terjadi karena struktur enzim mulai berubah, sehingga substrat tidak dapat berikatan dengan sisi aktif enzim dan proses katalis tidak dapat berlangsung dengan sempurna. Profil aktivitas $\mathrm{pH}$ enzim menggambarkan $\mathrm{pH}$ pada saat gugus pemberi atau penerima proton yang penting pada sisi katalitik enzim berada dalam tingkat ionisasi yang diinginkan. $\mathrm{pH}$ optimum enzim tidak harus sama dengan $\mathrm{pH}$ lingkungan normalnya, dengan $\mathrm{pH}$ yang mungkin sedikit berada di atas atau dibawah pH optimum (Nurkhotimah 2017).

Tingkat keasaman mempengaruhi aktivitas enzim tripsin.Enzim tripsin menurut Benjakul et al. (1997) merupakan enzim yang termasuk protease alkali. Tripsin dapat mengikat substrat dengan baik pada kondisi basa dan sebaliknya pada kondisi asam karena enzim akan mengalami denaturasi pada pH asam. Penelitian Santos et al. (2016) membuktikan bahwa pada $\mathrm{pH} 4$ dan 5 tripsin tidak memiliki aktivitas, sedangkan pada $\mathrm{pH}$ 6-11 menunjukkan adanya aktivitas, dengan aktivitas optimum pada $\mathrm{pH}$ 9. Kim dan Jeong (2012) juga menjelaskan bahwa tripsin memiliki aktivitas pada $\mathrm{pH}$ 7-10.

\section{Pengaruh Ion Logam terhadap Aktivitas Tripsin Usus Ikan Tongkol}

Jenis enzim memberikan reaksi yang berbeda terhadap beberapa jenis ion logam yang berbeda (Lehninger 1997). Analisis pengaruh ion logam untuk melihat pengaruhnya terhadap aktivitas tripsin.Hasil analisis dapat dilihat pada Table 3.

Table 3 Effect of metal ion $(0.005 \mathrm{M})$ to trypsin activity of little tuna

\begin{tabular}{lr}
\hline \multicolumn{1}{c}{ Metal Ion } & Activity (\%) \\
\hline Control & 100 \\
$\mathrm{Mn}^{2+}$ & $111 \pm 0.030$ \\
$\mathrm{Zn}^{2+}$ & $47 \pm 0.023$ \\
$\mathrm{Cu}^{2+}$ & $107 \pm 0.049$ \\
$\mathrm{Na}^{+}$ & $114 \pm 0.029$ \\
$\mathrm{Ca}^{2+}$ & $81 \pm 0.421$ \\
\hline
\end{tabular}

Aktivitas enzim tripsin mengalami penghambatan oleh $\mathrm{ZnCl}_{2}$ dan $\mathrm{CaCl}_{2}$. Penghambatan terbesar yaitu pada $\mathrm{ZnCl}_{2}$ dengan konsentrasi 0,005 $\mathrm{M}$ dengan aktivitas sebesar $47 \%$. Ion logam lain yaitu $\mathrm{MnCl}_{2}$, $\mathrm{CuCl}_{2}$, dan $\mathrm{NaCl}$ meningkatkan aktivitas enzim. Aktivitas tertinggi ditunjukkan oleh $\mathrm{NaCl}$ konsentrasi 0,005 M sebesar 114\%.

Salah satu karakteristik aktivitas enzim adalah memerlukan kofaktor. Tidak semua enzim dapat bekerja sendiri. Kofaktor merupakan gugus non protein dari enzim yang menentukan aktivitas katalitiknya. Senyawa kofaktor meliputi ion logam sederhana dan molekul organik (Wiseman 1985). Senyawa kofaktor yang berupa ion logam ada yang berpotensi meningkatkan aktivitas kerja suatu enzim yang disebut sebagai aktivator enzim, dan ada yang 
menghambat aktivitas enzim atau disebut inhibitor enzim (Sumardjo 2006). Menurut Green dan Neurath (1993) Keberadaan ion $\mathrm{Ca}$ dan $\mathrm{Mn}$ dapat meningkatkan aktivitas enzim sebesar $25 \%$. Sulistiyowati et al. (2016) menemukan bahwa ion $\mathrm{Cu}$ bersifat sebagai inhibitor dan ion $\mathrm{Zn}$ bersifat sebagai aktivator. Barkia et al. (2010) melaporkan bahwa enzim tripsin yang diisolasi dari jeroan ikan Bogou nyata dihambat oleh ion $\mathrm{Hg}^{2+}$ hingga aktivitas relatifnya menjadi $28 \%$.

\section{Pengaruh $\mathrm{NaCl}$ dengan Konsentrasi Berbeda Aktivitas Tripsin Usus Ikan Tongkol}

Pengujian $\mathrm{NaCl}$ dengan konsentrasi berbeda terhadap enzim tripsin dilakukan untuk melihat pengaruhnya terhadap aktivitas enzim. Hasil analisis pengaruh nilai $\mathrm{NaCl}$ $5-30 \%(\mathrm{~b} / \mathrm{v})$ terhadap aktivitas enzim dapat dilihat pada Figure 4.

Konsentrasi $\mathrm{NaCl}$ 5-30\% menunjukkan nilai yang relatif stabil terhadap aktivitas enzim. Barkia et al. (2010) dengan sampel ikan Boops boops melaporkan bahwa aktivitas relatif tripsin menunjukkan nilai $50 \%$ pada penambahan $\mathrm{NaCl}$ pada konsentrasi 35\% (b/v). Balti et al. (2009) dengan sampel ikan S. officinalis melaporkan bahwa aktivitas relatif $39,4 \%$ pada konsentrasi $\mathrm{NaCl} 35 \%$ (b/v). Hal ini menunjukkan bahwa tripsin dari usus ikan tongkol mampu bekerja dalam kondisi garam yang tinggi.

Proses yang terjadi ketika penambahan konsentrasi garam yang terus meningkat dapat disebut dengan salting out. Peningkatan konsentrasi $\mathrm{NaCl}$ menyebabkan meningkatnya kekuatan ionik sehingga terjadinya penurunan aktivitas enzim oleh interaksi hidrofobik antara protein dan garam untuk berikatan dengan air (Kita et al. 1994). Konsentrasi $\mathrm{NaCl}$ yang semakin meningkat menunjukkan aktivitas enzim yang relatif stabil. Aktivitas enzim tripsin yang masih stabil pada penambahan garam yang cukup tinggi menunjukkan potensi enzim tripsin dari usus ikan tongkol ini dapat digunakan dalam pengolahan pangan yang membutuhkan penambahan garam yang tinggi misalnya hidrolisis protein pada pembuatan kecap ikan (Barkia et al. 2010).

\section{Kinetika Tripsin Usus Ikan Tongkol}

Kinetika enzim berkaitan dengan kecepatan katalisis enzim dan faktorfaktor yang mempengaruhinya.Konsentrasi substrat merupakan salah satu faktor yang mempengaruhi aktivitas enzim (Wahyuni 2017). Hasil analisis pengaruh konsentrasi substrat dengan aktivitas tripsin dapat dilihat pada Figure 5 dan Figure 6.

Konsentrasi substrat 1-3,5 mM mempengaruhi aktivitas enzim dimana aktivitas meningkat dari konsentrasi $1 \mathrm{mM}$ sampai $3 \mathrm{mM}$. Aktivitas enzim padakonsentrasi substrat $3 \mathrm{mM}$ dan 3,5 $\mathrm{mM}$ menunjukkan nilai yang konstan yaitu masing-masing 0,307 $\mathrm{U} / \mathrm{mL}$ dan $0,308 \mathrm{U} / \mathrm{mL}$. Kecepatan reaksi $\left(\mathrm{V}_{\text {maks }}\right)$ dapat dihitung melalui persamaan Lineweaver-Burk (Figure 6). Hasil perhitungan

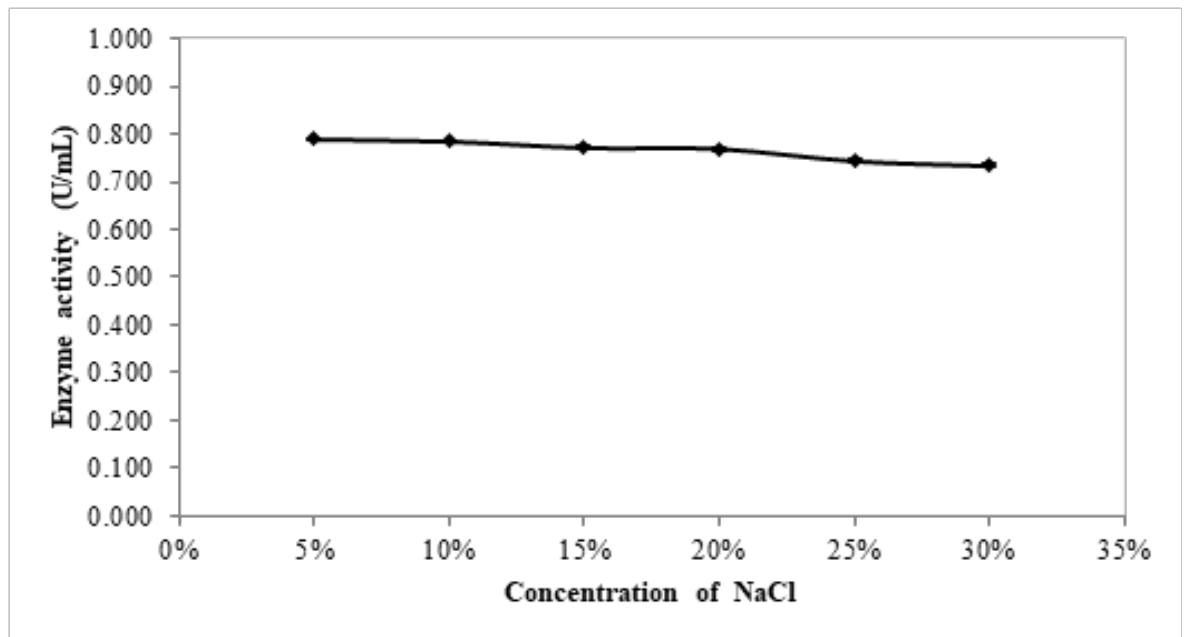

Figure 4 Stability of trypsin activity at $\mathrm{NaCl} 5-30 \%$ 


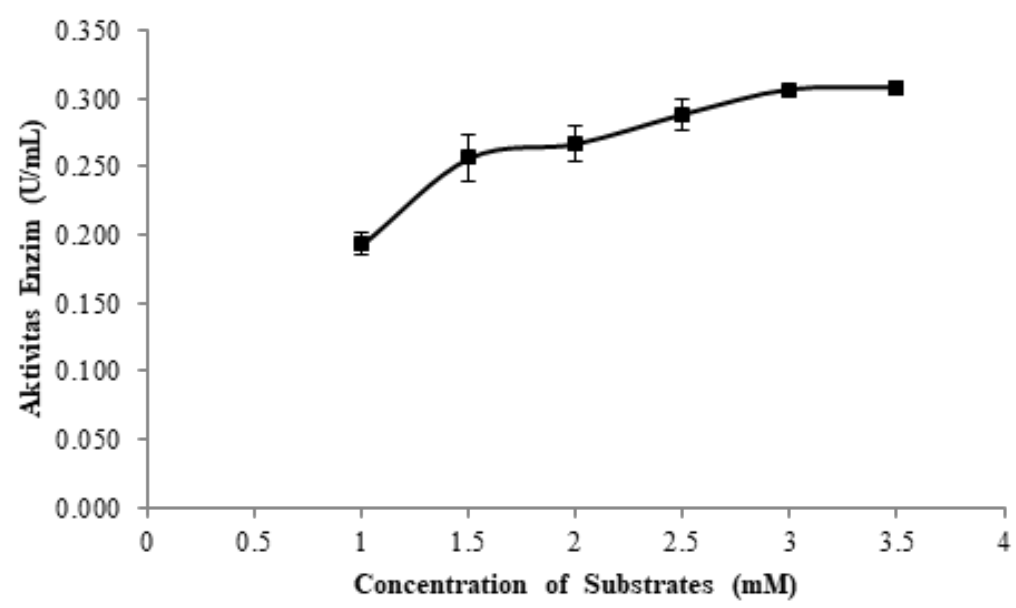

Figure 5 Trypsin activity at substrates concentration of 1-3.5 mM

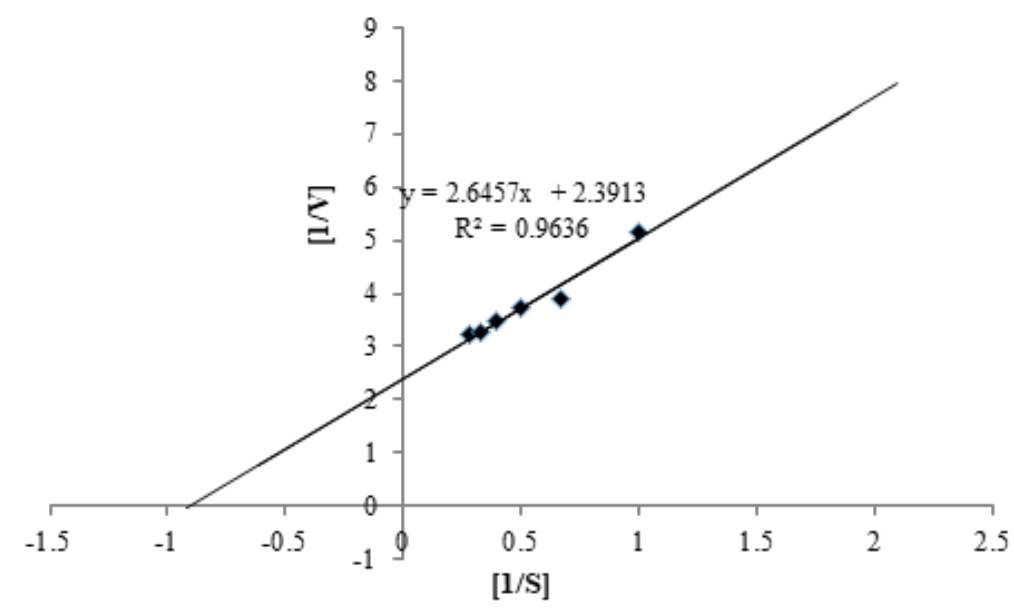

Figure 6 Reaction kinetics of trypsin enzyme

Lineweaver-Burk didapatkan nilai $\mathrm{V}_{\text {maks }}$ sebesar $0,42 \mathrm{mmol} / \mathrm{s}$. Nilai konstanta $\left(\mathrm{K}_{\mathrm{m}}\right)$ enzim menunjukkan konsentrasi substrat yang diperlukan enzim untuk mencapai setengah kelajuan maksimumnya. Menurut Lehninger (1997) nilai $\mathrm{V}_{\text {maks }}$ menunjukkan titik dimana enzim menjadi jenuh oleh substrat dan tidak dapat berfungsi lebih cepat. Penambahan konsentrasi substrat yang semakin tinggi setelah tercapainya titik ini, kecepatan reaksi akan mendekati tetapi tidak akan pernah mencapai maksimum.

Nilai $\mathrm{K}_{\mathrm{m}}$ tripsin usus ikan tongkol yang diperoleh pada penelitian yaitu 1,12 mM. Nilai $\mathrm{K}_{\mathrm{m}}$ tripsin yang diperoleh dari beberapa jenis ikan menunjukkan hasil yang berbedabeda. Nilai $\mathrm{K}_{\mathrm{m}}$ pada ikan Sardinelle (Sardinelle aurita) yaitu 1,670 mM (Khaled et al. 2008), Mustelus mustelus 0,387 (Bougatef et al. 2010),
Paralichthys olivaceus 0,017 mM (Kim dan Jeong 2012), dan Luphiosilurus alexandri 0,517 mM (Santos et al. 2016).

\section{KESIMPULAN}

Ekstrak kasar tripsin dari usus ikan tongkol memiliki aktivitas sebesar 0,205 U/ $\mathrm{mL}$. Aktivitas ekstrak kasar tripsin mengalami peningkatan setelah dilakukan pengendapan pada fraksi amonium sulfat $40-50 \%$. Enzim tersebut memiliki suhu dan $\mathrm{pH}$ optimum pada $60^{\circ} \mathrm{C}$ dan 9. Ion logam $\mathrm{ZnCl}_{2}$ dan $\mathrm{CaCl}_{2}$ menghambat aktivitas enzim, sedangkan $\mathrm{MnCl}_{2}, \mathrm{CuCl}_{2}$, dan $\mathrm{NaCl}$ meningkatkan aktivitas enzim. Enzim tripsin relatif stabil dalam larutan $\mathrm{NaCl}$ 5-30\%. Nilai konstanta $\left(\mathrm{K}_{\mathrm{m}}\right)$ enzim tripsin usus ikan tongkol yaitu $1,12 \mathrm{mM}$ dan $\mathrm{V}_{\text {maks }}$ sebesar $0,42 \mathrm{mmol} / \mathrm{s}$. 


\section{DAFTAR PUSTAKA}

Balti R, Barkia A, Bougatef N, Ktari N, Nasri M. 2009. Heatstable trypsin from cuttlefish (Sepia officanalis) hepatopancreas: purification and characterization. Food Chemistry.113: 146-154.

Barkia A, Bougatef A, Nasri R, Fetoui E, Balti R, Nasri M. 2010. Trypsin from the viscera of Bogue (Boop boops): isolation and characterization. Fish Physiology Biochemistry.36: 893-902.

Benjakul S, Morrissey MT. 1997. Protein hydrolysates from pacific whiting solid wastes. Journal of Agricultural Food Chemistry. 45 (9): 3423-3430.

Bougatef A, Souissi N, Fakhfakh N, Ellouztriki Y, Nasri M. 2007. Purification and characterization of trypsin from the viscera of sardine (Sardina pilchardus). Food Chemistry. 102: 343-350.

Bradford MM. 1976. A rapid and sensitive method for the quantitation of microgram quantities of protein utilizing the principle of protein-dye binding. Analytical Biochemistry.72: 248-254.

Burgess RR. 2009. Protein precipitation techniques. Di dalam: Burgess dan Murray, editor. Methods in Enzymology volume 463. Wisconsin (US): Elsevier Inc. hlm 331-342.

Chodrijah U, Hidayat T, Noegroho T. 2013. Estimasi parameter populasi ikan tongkol komo (Euthynnus affinis) di perairan laut jawa. BAWAL. 5(3): 167-174.

Falch EA. 1991. Industrial enzymes developments in production and application. Biotechnology advances. 9(4): 643-658.

Gorman DP, Horn MH, Gawlicka A. 2004. Digestive Enzyme Activities in Herbivorous and Carnivorous Prickleback Fishes (Teleostei: Stichaeidae): Ontogenetic, Dietary, and Phylogenetic Effects. Physiological and Biochemical Zoology 77(5):789-804. 2004.

Green AA, Hughes WL. 1955. Protein solubility on the basic of solubility in aqueous solutions of salts and organic solvent. Methods Enzymology.1: 67-90.

Green NM, Neurath H. 1953. The effect of divalent cations on trypsin. Journal of
Biological Chemistry. 204(1): 379-390.

Grizelle JM, Roger WA. 2003. Anatomy and histology of the freshwater. (USA): Departement of Fisheries And Applied Aquaculture, Auburn University

[Kemerisetdikti] Kementrian Riset, Teknologi, dan Pendidikan Tinggi Republik Indonesia (ID). 2017. Kemandirian Produk Enzim Indonesia. https://www. ristekdikti.go.id/kabar/kemandirianproduk-enzim-indonesia/

Khaled HB, Jellouli K, Souissi N, Ghorbel S, Barkia A, Nasri M. 2011. Purification and characterization of three trypsin isoforms from viscera of sardinelle (Sardinella aurita). Fish Physiology and Biochemistry. 37(1): 123-133.

Kramer DL, Bryant MJ. 1995. Intestine lenght the fishes of a tropical stream: 1 Ontogenic allometry, 2 relation to diet the long and short of a convoluted issue. Environtmental Biology Fish. 42(2): 115141.

Khandagale AS, Mundodi L, Sarojini BK. 2017. Isolation and characterization of trypsin from fish viscera of oil sardine (Sardinella longiceps).International Journal of Fisheries and Aquatic Studies. 5(2): 33-37.

Kim M, Jeong Y.2012. Purification and characterization of trypsin-like protease from faltfish (paralichthy olivaceus) intestine. Journal of Food Biochemistry. 37: 732-741.

Kita Y, Arakawa T, Lin TY, Timasheff S. 1994. Contribution of the surface free energy perturbations to protein solvent interactions. Biochemistry. 33: 1517815189.

Kosim M. 2009. Pengaruh suhu pada protease dari Bacillus subtilis [skripsi]. Surabaya (ID): Institut Teknologi Sepuluh Nopember.

Lehninger AL. 1997. Dasar-Dasar Biokimia. Thenawidjaja M, penerjemah; Suwarman, editor. Jakarta (ID): Penerbit Erlangga Terjemahan dari: Principle of Biochemistry.

Li ZY, Youravong w, H-Kittikun A. 2006. Separation of protease from yellowfin tuna spleen by ultrafiltration. Bioresource Technology. 97(18): 2364-2370. 
Moniharapon T, Pattipeilohy F. 2016. Pemanfaatan daging merah dari limbah tuna loin dalam pengolahan kecap ikan. Majalah Bahan Alam, Industri, Aneka Pangan, Minyak Atsiri. 12(1): 27-31.

Muallifah AY. 2017. Mengurai hadis tahnik dan gerakan anti vaksin. Jurnal Living Hadis. 2(2): 253-269.

Nurkhotimah. 2017. Pengaruh suhu dan $\mathrm{pH}$ terhadap aktivitas enzim fosfatase bakteri termofilik sungai gendol pasca erupsi merapi. Jurnal Prodi Biologi. 6(8): 465471.

Oktavianto D, Susilo U, Priyanto S. 2014. Respon aktivitas amylase dan protease ikan gurami Osphronemus gouramy Lac. terhadap perbedaan temperature air. Scripta Biologica. 1(4): 14-18.

Parfitt K. 1999. Martindale and Complete Drug Reference. Ed ke-13. (USA): Pharmaceutical Press.

Pasaribu E, Nurhayati T, Nurilmala M. 2018. Ekstraksi dan karakterisasi enzim pepsin dari lambung ikan tuna (Thunnus albacares). Jurnal Pengolahan Hasil Perikanan Indonesia 21(3): 486-496.

Ranasasmita R. 2015. Kehalalan produk obatobatan, terutama obat herbal. Di dalam: Ranasasmita R, Roswiem AP, editor. Prosiding Simposium Penelitian Bahan Obat Alami XIV [Internet]. [Waktu dan tempat pertemuan tidak diketahui]. Bogor(ID): Institut Pertanian Bogor. Hlm 552-559; [diunduh 2018 Nov 4] Tersedia pada: http://xdocs.net/previewmakalahhalal-5bf 85 c 45

Santos CWVd, Marques MEdS, Tenoroi HdA, Miranda ECd, Pereria HJV. 2016. Purification and characterization of trypsin Luphiosilurus alexandri. Biochemistry and Biophysics Report .8: 2933.

Silva JF, Esposito TS, Marchuschi M, Ribeiro K, Cavalli RO, Oliveira V, Bezerra RS. 2011.
Purification and partial characterization of a trypsin from the processing waste of the silver mojarra (Diapterus rhombeus). Food Chemistry. 129(3): 777-782.

Sinaga M, Nugroho TT, Dahliaty A. 2014. Pemekatan enzim selulase Penicillium sp. LBKURCC20 dengan pengendapan amonium sulfat $80 \%$. Jurnal Online Mahasiswa Fakultas Matematika dan Ilmu Pengetahuan Alam Universitas Riau.1(2): 283-288.

Suhartono MT. 1989. Enzim dan Bioteknologi. Bogor (ID): Departemen Pendidikan dan Kebudayaan, Direktorat Jenderal Pendidikan Tinggi Antar Universitas Bioteknologi, Institut Pertanian Bogor.

Sulistyowati E, Salirawati D, Amanatie. 2016. Karakterisasi beberapa ion logam terhadap aktivitas enzim tripsin. Jurnal Penelitian Saintek. 21(2): 107-119.

Sumardjo D. 2006. Pengantar Kimia: Buku Panduan Kuliah Mahasiswa Kedokteran dan Program Satrata I Fakultas Bioeksakta. Jakarta (ID): Penerbit Buku Kedokteran EGC.

Teich N, Nemoda Z, Kohler H, Heinritz W, Mossner J, Keim V, Sahin-Toth M. 2005. Gene conversion between functional tripsinogen genes PRSS1 and PRSS2 associated with chronic pancreatitis in a six-year-old girl. Human Mutatation. 25(4): 343-347.

Wahyuni S. 2017. Biokimia Enzim dan Karbohidrat. Lhokseumawe (ID): Unimal Press

Whitaker JR. 1994. Principles of Enzymology for the Food Science $2^{\text {nd }}$ Edition. New York (USA): Marcel Dekker Inc.

Wiseman A. 1985. Handbook of Enzyme Biotechnology Second Edition. Chicester (US): Ellis Hordwood Limited.

Yazid E. 2006. Penuntun Praktikum Biokimia Untuk Mahasiswa Analisis. Jakarta (ID): Graha Ilmu. 